\title{
Penggunaan Mineralocorticoid Receptor Antagonist pada Heart Failure Reduced Ejection Fraction
}

\author{
David H. P. Sihombing, ${ }^{1}$ Natalia C. I. Polii, ${ }^{2}$ Agnes L. Panda ${ }^{2}$
}

\author{
${ }^{1}$ Program Studi Pendidikan Dokter Fakultas Kedokteran Universitas Sam Ratulangi, Manado, \\ Indonesia \\ ${ }^{2}$ Bagian Ilmu Penyakit Jantung dan Pembuluh Darah Fakultas Kedokteran Universitas Sam \\ Ratulangi, Manado, Indonesia \\ Email: hsihombing2599@gmail.com
}

\begin{abstract}
Heart failure reduction ejection fraction (HFrEF) is heart failure associated with decreased ejection fraction. It is characterized by abnormalities in cellular calcium regulation and changes in calcium kinetics that cause contraction changes in the myocardium. According to the European Society of Cardiology, mineralocorticoid receptor antagonist (MRA) is used as an adjunct drug when the first-line drugs are not sufficient to treat heart failure. This class of drugs has been shown to be very effective in use in HFrEF patients as shown in The Randomized Aldactone Evaluation Study (RALES), therefore, its use has been approved by the Food and Drug Administration (FDA). This study was aimed to analyze the effectiveness of MRA on HfrEF. This was a literature review study. The results showed that the use of MRA had significant benefits in reducing morbidity, mortality, and re-hospitalization in HFrEF patients. Improvements shown by the use of MRA included increased level of brain natriuretic peptide (BNP), improved NYHA classification, and decreased patient weight. A side effect that needs to be considered was hyperkalemia, whereas hypotensive effect was not of great concern because MRA was rarely reported to cause hypotension even when the initial systolic blood pressure is low. In conclusion, mineralocorticoid receptor antagonist is useful to improve the outome of HFrEF patients.
\end{abstract}

Keywords: heart failure, heart failure reduced ejection fraction (HFrEF), mineralocorticoid receptor antagonist (MRA)

\begin{abstract}
Abstrak: Heart Failure reduced Ejection Fraction (HFrEF) merupakan gagal jantung disertai penurunan fraksi ejeksi. Kondisi ini ditandai dengan adanya kelainan regulasi kalsium seluler dan perubahan kinetika kalsium yang menyebabkan terjadinya perubahan kontraksi miokardium. Menurut European Society of Cardiology, mineralocorticoid receptor antagonist (MRA) digunakan sebagai obat tambahan bila obat lini pertama tidak cukup untuk mengatasi gagal jantung. Obat golongan ini terbukti sangat efektif digunakan pada pasien HFrEF sebagaimana yang ditunjukkan pada penelitian The Randomized Aldactone Evaluation Study (RALES), sehingga penggunaannya telah disetujui oleh Food and Drugs Administration (FDA). Penelitian ini bertujuan untuk menganalisis efektifitas penggunaan MRA pada pasien HFrEF. Jenis penelitian ialah literature review. Hasil penelitian memperlihatkan bahwa penggunaan MRA memiliki manfaat yang bermakna untuk menurunkan morbiditas, mortalitas, dan rawat inap ulang pada pasien HFrEF. Perbaikan yang ditunjukkan oleh penggunaan MRA antara lain peningkatan kadar Brain Natriuretic Peptide (BNP), perbaikan klasifikasi NYHA, dan penurunan berat badan pasien. Efek samping yang perlu menjadi pertimbangan ialah hiperkalemia, sedangkan efek hipotensi tidak terlalu dikhawatirkan karena MRA dilaporkan jarang menyebabkan hipotensi bahkan ketika tekanan darah sistolik awal rendah. Simpulan penelitian ini ialah mineralocorticoid receptor antagonist bermanfaat untuk memperbaiki luaran pada pasien HFrEF.
\end{abstract}

Kata kunci: gagal jantung, heart failure reduced ejection fraction (HFrEF), mineralocorticoid, receptor antagonist (MRA) 


\section{PENDAHULUAN}

Heart Failure (HF) atau gagal jantung merupakan keadaan gagalnya organ jantung untuk membawa oksigen yang dibutuhkan tubuh untuk kebutuhan metabolisme jarringan walaupun dengan tekanan pengisian jantung untuk memompa darah dalam batas normal atau adanya peningkatan. Gejala klinis yang khas ditimbulkan dari gagal jantung antara lain sesak napas, edema ekstermitas bawah, kelelahan, adanya peningkatan tekanan vena jugularis, dan bising paru. Berdasarkan nilai dari pengukuran left ventricular ejection fraction (LVEF), HF diklasifikasikan menjadi tiga jenis berdasarkan fraksi ejeksi, yaitu HF with preserved ejection fraction ( $\mathrm{HFpEF})$, $\mathrm{HF}$ with reduced ejection fraction ( $\mathrm{HFrEF})$, dan $\mathrm{HF}$ with mid-range ejection fraction (HFmrEF). ${ }^{1,2}$

Fraksi ejeksi adalah persentase volume darah yang dipompa keluar oleh ventrikel kiri dibandingkan dengan volume darah yang masuk ke ventrikel kiri. HF with preserved ejection fraction ( $\mathrm{HFpEF}$ ) merupakan gagal jantung dengan fraksi ejeksi tetap normal. Kondisi ini disebabkan oleh kegagalan jantung melakukan relaksasi isovolumik ventrikel kiri yang berakibat terjadinya perpanjangan, keterlambatan pengisian ventrikel kiri, dan peningkatan kekakuan ventrikel kiri. HF with mid-range ejection fraction (HFmrEF) merupakan transisi dari HFrEF dan HFpEF. Pasien yang mengalami HFmrEF memiliki risiko lebih rendah terjadinya disfungsi sistolik dan disfungsi diastolik. HF with reduced ejection fraction (HFrEF) merupakan gagal jantung dengan adanya penurunan fraksi ejeksi. Kondisi ini disebabkan oleh keadaan dari suatu penyakit yang memengaruhi organ jantung yang berakibat terjadinya penurunan kontraksi ventrikel jantung. Suatu HFrEF ditandai oleh adanya kelainan regulasi kalsium seluler dan perubahan kinetika kalsium yang menyebabkan terjadinya perubahan kontraksi miokardium. ${ }^{3,4}$

Secara global HF merupakan 10 penyakit dengan angka kematian tertinggi. Heart failure menjadi salah satu masalah kesehatan yang dialami lebih dari 26 juta orang. Pada negara maju tercatat sebanyak 1-2\% penderita HF tergolong kelompok dengan rentang usia dewasa. Tercatat angka kematian HF yang terjadi setiap tahun sebanyak 278.000 jiwa. Angka prevalensi tersebut mengalami peningkatan secara bermakna dengan sasaran $6-10 \%$ pada kelompok usia di atas 65 tahun. ${ }^{5}$ Berdasarkan laporan hasil Riskesdas (2019) tercatat kasus HF di Indonesia sebanyak 13.395 jiwa yang menjalani rawat inap dan 16.431 jiwa yang menjalani rawat jalan. Indonesia memiliki persentase case fatality rate (CFR) untuk kasus HF yaitu 13,42\%. Tiga provinsi di Indonesia yang memiliki angka prevalensi kejadian HF tertinggi yaitu DI Yogyakarta $(0,25 \%)$, Jawa Timur $(0,19 \%)$, dan Jawa Tengah $(0,18 \%)$. Angka tersebut menunjukkan bahwa HF masih menjadi salah satu penyakit yang paling banyak dialami oleh masyarakat yang dapat menyebabkan penurunan kualitas hidup. ${ }^{7}$

Mineralocorticoid Receptor Antagonist (MRA) atau antagonis aldosteron merupakan salah satu terapi farmakologi yang digunakan dalam pengobatan HF jantung. Obat golongan ini terbukti sangat efektif pada pasien HFrEF sebagaimana yang ditunjukkan pada penelitian the Randomized Aldactone Evaluation Study (RALES), sehingga penggunaannya telah disetujui oleh Food and Drugs Administration (FDA). ${ }^{8}$ MRA merupakan golongan obat yang terdiri dari spironolakton, eplerenone, dan canrenone dan bekerja dengan cara memblokir reseptor yang mengikat aldosteron yang dapat meningkatkan remodeling dan disfungsi ventrikel jantung dengan berbagai tingkat afinitas, hormon steroid seperti kortikosteroid dan androgen. ${ }^{9}$ Penggunaan obat ini cukup luas pada praktek sehari-hari. Guideline terapi HF yang diterbitkan oleh European Society of Cardiology (ESC) pun memberikan tempat bagi obat golongan ini untuk digunakan sebagai tambahan ketika obat lini pertama tidak cukup untuk mengatasi HF. ${ }^{2,9}$

\section{METODE PENELITIAN}

Penelitian ini merupakan suatu literature review. Data yang digunakan 
dalam penelitian ini diperoleh dengan menggunakan tiga database yaitu Pubmed, ClinicalKey, dan Google Scholar. Kata kunci dalam pencarian artikel yaitu "mineralocorticoid receptor antagonist for heart failure reduced ejection fraction" atau berbagai variasi dan terjemahannya.

Literatur yang diperoleh kemudian diseleksi kembali dan diuraikan pada diagram prisma. Strategi yang digunakan untuk mencari literatur yaitu menggunakan Population, Intervention, Comparison, Outcomes (PICOS). Population yang dipilih ialah pasien $\mathrm{HFrEF}$, intervention yang dipilih ialah terapi MRA, no comparators, dan outcomes yang dituju ialah perbaikan klinis, perburukan klinis, kematian, dan prognosis. Study design yang ditelaah ialah dengan metode Systematic review, randomized controlled trial, case control, kohort, dan cross sectional dengan tahun publikasi dari 2010 hingga 2020.

\section{HASIL PENELITIAN}

Hasil pengumpulan artikel diperoleh dari penelusuran di google scholar, PubMed, dan Science Direct dengan menggunakan kata kunci Mineralocorticoid Receptor Antagonist AND Heart Failure with reduce Ejection Fraction. Literatur yang diperoleh sebanyak 3.000 artikel yang setelah disaring berdasarkan kriteria yang telah ditetapkan sebelumnya maka didapatkan sembilan artikel.

Tabel 1 memperlihatkan hasil kajian literatur yang dipakai dalam penelitian ini yang mencakup judul dan acuan pustaka, metode penelitian, hasil/simpulan, dan jurnal publikasi.

Tabel 2 memperlihatkan hasil penggunaan MRA pada pasien dengan $\mathrm{HF}$ with preserved ejection fraction $(\mathrm{HFpEF})$

Tabel 1. Hasil kajian literatur penelitian

\begin{tabular}{|c|c|c|c|c|}
\hline No & Judul dan penulis & $\begin{array}{c}\text { Metode } \\
\text { penelitian }\end{array}$ & Hasil/Simpulan & $\begin{array}{c}\text { Jurnal } \\
\text { publikasi }\end{array}$ \\
\hline 1 & $\begin{array}{l}\text { Mineralocorticoid receptor } \\
\text { antagonist pattern of use in } \\
\text { heart failure with reduced } \\
\text { ejection fraction: findings } \\
\text { from BIOSTAT-CHF }{ }^{58}\end{array}$ & $\begin{array}{l}\text { Prospective study } \\
\text { dengan } 1325 \text { sam- } \\
\text { pel penelitian }\end{array}$ & $\begin{array}{l}\text { MRA pada awal diagnosis dan pada } \\
\text { perawatan bulan ke-9 tidak berhu- } \\
\text { bungan dengan luaran kematian atau } \\
\text { rawat inap karena gagal jantung (HR } \\
1,02 \text {, CI95\% 0,66-1,58; } \mathrm{P}=0,93) \text {. }\end{array}$ & $\begin{array}{l}\text { European } \\
\text { Journal of Heart } \\
\text { Failure }\end{array}$ \\
\hline 2 & $\begin{array}{l}\text { Mineralocorticoid receptor } \\
\text { antagonist use after hospi- } \\
\text { talization of patients with } \\
\text { heart failure and post- } \\
\text { discharge outcomes: a } \\
\text { single-center retrospective } \\
\text { cohort study }{ }^{59}\end{array}$ & $\begin{array}{l}\text { Retrospective } \\
\text { cohort study de- } \\
\text { ngan } 1009 \text { sampel } \\
\text { penelitian }\end{array}$ & $\begin{array}{l}\text { MRA yang diberikan saat pulang } \\
\text { tidak berhubungan dengan kematian } \\
\text { atau rawat inap ulang pada hari ke- } 30 \\
\text { dan } 180\end{array}$ & $\begin{array}{l}\text { BMC } \\
\text { Cardiovascular } \\
\text { Disorder }\end{array}$ \\
\hline 3 & $\begin{array}{l}\text { Mineralocorticoid receptor } \\
\text { antagonists for heart failure: } \\
\text { a real-life observational } \\
\text { study } 60\end{array}$ & $\begin{array}{l}\text { Cohort study de- } \\
\text { ngan } 6046 \text { sampel } \\
\text { penelitian }\end{array}$ & $\begin{array}{l}\text { Pada } 10 \text { tahun masa tindak lanjut, } \\
\text { kelompok yang tidak diobati dengan } \\
\text { MRA memiliki jumlah kejadian } \\
\text { kematian karena penyakit kardiovas- } \\
\text { kular, transplantasi jantung urgent, } \\
\text { dan pemasangan left ventricular } \\
\text { assist device yang secara bermakna } \\
\text { lebih rendah daripada kelompok } \\
\text { yang diobati dengan MRA } \\
\text { (P<0,001). Pasien yang diobati } \\
\text { dengan MRA dan pasien yang tidak } \\
\text { diobati menunjukkan nilai titik akhir } \\
\text { penelitian yang serupa. }\end{array}$ & $\begin{array}{l}\text { ESC } \\
\text { Failure }\end{array}$ \\
\hline 4 & $\begin{array}{l}\text { Mineralocorticoid receptor } \\
\text { antagonists, blood pressure, } \\
\text { and outcomes in heart } \\
\text { failure with reduced }\end{array}$ & $\begin{array}{l}\text { Clinical trial de- } \\
\text { ngan } 4396 \text { sampel } \\
\text { penelitian }\end{array}$ & $\begin{array}{l}\text { Pengobatan MRA memiliki sedikit } \\
\text { efek pada tekanan darah sistolik pada } \\
\text { pasien dengan HFrEF. Pengobatan } \\
\text { MRA jarang menyebabkan hipotensi, }\end{array}$ & JACC Journal \\
\hline
\end{tabular}


ejection fraction ${ }^{61}$

5 The role of mineralocorticoid receptor antagonists in heart failure with reduced ejection fraction ${ }^{62}$

6 Reduced risk of hyperkalemia during treatment of heart failure with mineralocorticoid receptor antagonists by use of sacubitril/ valsartan compared with enalapril ${ }^{63}$

7 A comparison between both mineralocorticoid receptor antagonist agents (eplerenone and spironolactone) in prognosis of heart failure with reduced ejection fraction (HFrEF) ${ }^{64}$

8 Utilization of mineralocorticoid receptor antagonists in an advanced heart failure and transplant program in The Middle East ${ }^{65}$

9 Mineralocorticoid receptor antagonists for heart failure: systematic review and metaanalysis 66 bahkan ketika tekanan darah sistolik awal rendah

Clinical trial de- Di antara pasien HFrEF yang diobati ngan 8399 orang dengan MRA, hiperkalemia parah sampel penelitian lebih mungkin terjadi selama pengo-

Cohort study dengan 100 sampel penelitian

\section{Retrospective} cohort study dengan 123 sampel penelitian

Meta analysis dengan 16321 sampel penelitian
MRA menunjukkan manfaat yang bermakna untuk morbiditas dan mortalitas, di seluruh spektrum HFrEF, termasuk pasien setelah infark miokard akut batan dengan enalapril dibandingkan dengan sakubitril/valsartan

Bentham

Science

Publishers

JAMA

Cardiology

MRA adalah jalur pengobatan penting pada pasien gagal jantung. Eplerenon dan spironolakton memiliki hasil yang baik dalam meningkatkan tingkat Brain Natriuretic Peptide (BNP) dan meningkatkan klasifikasi NYHA, serta penurunan berat badan pasien.

Terapi MRA berhubungan dengan perbaikan fungsi ginjal dan kalium serum, tetapi tidak memengaruhi tekanan darah sistolik

MRA berhubungan dengan penurunan risiko kematian kardiovaskular (RR 0,81 [0,75-0,87], I2 0\%), semua penyebab kematian (RR 0,83 [0,770,88], I2 0\%), dan rawat inap karena penyakit jantung (RR 0,80 [0,70 0,92], I2 58,4\%). Namun MRA juga berhubungan dengan peningkatan risiko hiperkalemia (RR 2,03 [1,782,31], I2 0\%)
The Egyptian Journal of Hospital Medicine

Journal of Cardiac Failure

BMC

Cardiovascular Disorders

Tabel 2. Penggunaan MRA pada heart failure reduced ejection

\begin{tabular}{|c|c|c|}
\hline Artikel & Informasi Utama & Informasi Tambahan \\
\hline No-1 & $\begin{array}{l}\text { Penggunaan MRA tidak berhubungan dengan outcome } \\
\text { kematian atau rawat inap karena gagal jantung }\end{array}$ & - \\
\hline No-2 & $\begin{array}{l}\text { Penggunaan MRA tidak berhubungan dengan outcome } \\
\text { kematian atau rawat inap ulang }\end{array}$ & - \\
\hline No-3 & $\begin{array}{l}\text { Penggunaan MRA tidak efektif menurunkan angka } \\
\text { kematian karena penyakit kardiovaskular, transplantasi } \\
\text { jantung urgent, dan pemasangan left ventricular assist } \\
\text { device }\end{array}$ & - \\
\hline No-4 & $\begin{array}{l}\text { Penggunaan MRA berhubungan dengan perbaikan semua } \\
\text { komponen outcome }\end{array}$ & $\begin{array}{l}\text { Penggunaan MRA memili- } \\
\text { ki sedikit efek pada tekanan } \\
\text { darah sistolik. Pengobatan } \\
\text { MRA jarang menyebabkan } \\
\text { hipotensi, bahkan ketika } \\
\text { tekanan darah sistolik awal } \\
\text { rendah }\end{array}$ \\
\hline No-5 & $\begin{array}{l}\text { Penggunaan MRA menunjukkan manfaat yang bermak- } \\
\text { na untuk morbiditas dan mortalitas }\end{array}$ & $\begin{array}{l}\text { Manfaat terlihat pada selu- } \\
\text { ruh spektrum HFrEF, ter- }\end{array}$ \\
\hline
\end{tabular}




\begin{tabular}{cll}
\hline & & \multicolumn{1}{c}{$\begin{array}{c}\text { masuk pasien pasca infark } \\
\text { miokard akut }\end{array}$} \\
No-6 & $\begin{array}{l}\text { Kombinasi penggunaan MRA dan enalapril lebih mung- } \\
\text { kin meningkatkan keparahan hiperkalemia, daripada } \\
\text { penggunaan MRA dan sakubitril/valsartan }\end{array}$ \\
No-7 & $\begin{array}{l}\text { Penggunaan MRA (eplerenon dan spironolakton) } \\
\text { memiliki hasil yang baik dalam meningkatkan tingkat }\end{array}$ \\
& $\begin{array}{l}\text { Brain Natriuretic Peptide (BNP) dan meningkatkan } \\
\text { klasifikasi NYHA, serta penurunan berat badan pasien. }\end{array}$ \\
No-8 & $\begin{array}{l}\text { Penggunaan MRA berhubungan dengan perbaikan fungsi } \\
\text { ginjal dan kalium serum, tetapi tidak memengaruhi } \\
\text { tekanan darah sistolik } \\
\text { Penggunaan MRA berhubungan dengan penurunan risiko } \\
\text { kematian kardiovaskular dan rawat inap karena penyakit } \\
\text { jantung }\end{array}$ \\
\hline
\end{tabular}

\section{BAHASAN}

Hasil scoping artikel menunjukkan terdapat delapan laporan penelitian yang dapat digunakan untuk menjawab rumusan masalah penelitian ini. Terdapat tiga penelitian yang menyatakan bahwa penggunaan MRA tidak berhubungan dengan berbagai outcome pada HFrEF. Penelitian yang dilakukan oleh Ferreira et $a^{58}$ dan Durstenfeld et $\mathrm{al}^{59}$ menyatakan bahwa penggunaan MRA tidak berhubungan dengan mortalitas atau rawat inap ulang karena gagal jantung. Bruno et $\mathrm{al}^{60}$ juga melaporkan bahwa penggunaan MRA tidak berhubungan dengan mortalitas, urgensi untuk melakukan transplantasi jantung, dan pemasangan left ventricular assist device (LVAD).

Sementara itu, terdapat lima penelitian yang melaporkan manfaat penggunaan MRA pada pasien HFrEF. Penelitian yang dilakukan oleh Serenelli et $a l,{ }^{61}$ Papademetriou et $\mathrm{al}^{62}$ serta Berbenetz dan Mrkobrada $^{66}$ (2016) menunjukkan bahwa penggunaan MRA memiliki manfaat yang bermakna untuk menurunkan morbiditas, mortalitas, dan rawat inap ulang pada pasien HFrEF. Perbaikan luaran lain karena penggunaan MRA juga ditampilkan pada penelitian Saleh et $\mathrm{al}^{64}$ yang mendapatkan bahwa penggunaan MRA (eplerenon dan spironolakton) akan meningkatkan kadar Brain Natriuretic Peptide (BNP), memperbaiki klasifikasi NYHA, dan menurunkan berat badan pasien. Penggunaannya pada pasien dengan gangguan fungsi ginjal juga menunjukkan hasil yang positif. Alsoud et $\mathrm{al}^{65}$ melaporkan bahwa penggunaan MRA berhubungan dengan perbaikan fungsi ginjal dan kalium serum, tetapi tidak memengaruhi tekanan darah sistolik.

Efek samping hiperkalemia harus menjadi salah satu pertimbangan dalam penggunaan MRA karena beberapa penelitian melaporkan bahwa penggunaan MRA berhubungan dengan kejadian hiperkalemia, sebagaimana yang disampaikan oleh Desai et al $^{63}$ serta Berbenetz dan Mrkobrada. ${ }^{66}$ Penelitian yang dilakukan oleh Desai et al ${ }^{63}$ juga menyatakan bahwa terjadinya hiperkalemia berat terkait dengan penggunaan MRA dan enalapril, tetapi lebih jarang ditemukan pada penggunaan MRA dan sakubitril/valsartan. Sementara itu efek samping hipotensi tidak perlu dikhawatirkan karena penelitian yang dilakukan Serenelli et $\mathrm{l}^{61}$ melaporkan bahwa penggunaan MRA hanya memiliki sedikit efek pada tekanan darah sistolik. Pengobatan MRA jarang menyebabkan hipotensi, bahkan ketika tekanan darah sistolik awal rendah.

Berdasarkan uraian di atas, terlihat bahwa penggunaan MRA terbukti bermanfaat terhadap luaran HFrEF pada lima artikel penelitian namun tidak terbukti bermanfaat pada tiga artikel penelitian. Masing-masing penelitian tersebut menggu-nakan desain penelitian berkualitas tinggi, yaitu cohort dan clinical trial. Dengan melihat perbandingan jumlah literatur, maka disimpulkan bahwa penggunaan MRA bermanfaat pada 
pasien HFrEF untuk memperbaiki luaran morbiditas dan mortalitas pasien.

Penelitian ini memiliki beberapa keterbatasan. Pertama, penelitian ini ini tidak menganalisis berbagai karakteristik subjek yang digunakan dalam penelitian yang dikaji oleh karena tidak semua penelitian acuan mencantumkan secara lengkap karakteristik subjek penelitiannya. Kedua, pada penelitian ini digunakan laporan penelitian dengan jenis penelitian yang sangat variatif. Hal ini disebabkan karena terbatasnya laporan penelitian dengan satu metode tertentu, misalnya hanya kohort. Namun demikian, karena tidak dilakukan meta-analisis, maka metode penelitian yang sangat variatif tersebut tidak menjadi masalah.

\section{SIMPULAN}

Penggunaan mineralocorticoid receptor antagonist bermanfaat untuk memperbaiki outcome pada pasien heart failure reduced ejection fraction.

Bagi penelitian selanjutnya isarankan untuk menggunakan populasi berbeda, misalnya pasien HFmrEF atau HFpEF. Disarankan bagi para klinisi untuk mempertimbangkan penggunaan MRA pada pasien HFrEF karena telah terbukti bermanfaat untuk memperbaiki luaran pasien

\section{Konflik Kepentingan}

Penulis menyatakan tidak terdapat konflik kepentingan dalam studi ini.

\section{DAFTAR PUSTAKA}

1. Metra M, Teerlink JR. Heart failure. The Lancet. 2017;390(10106):1981-95

2. Ponikowski P, Voors AA, Anker SD, Bueno H, Cleland JGF, Coats AJS, et al. 2016 ESC Guidelines for the diagnosis and treatment of acute and chronic heart failure. Eur Heart J. 2016;37(27):2129200.

3. Brahmbhatt DH, Cowie MR. Heart failure: classification and pathophysiology. Medicine (United Kingdom). 2018; 46(10):587-93.

4. Pearse SG, Cowie MR. Heart failure: Classification and pathophysiology. Medicine (United Kingdom). 2014;
42(10):556-61.

5. World Health Organization. WHO - The top 10 causes of death. 24 Maggio. 2018:1-7.

6. Kementerian Kesehatan RI. Riset Kesehatan Dasar Tahun 2018. Jakarta, 2018. Available from: https://kesmas.kemkes. go.id/assets/upload/dir_519d41d8cd98f 00/files/Hasil-riskesdas-2018_1274.pdf

7. Pitt B, Zannad F, Remme WJ, Cody R, Castaigne A, Perez A, et al. The effect of spironolactone on morbidity and mortality in patients with severe heart failure. N Engl J Med. 1999;341(10): 709-17.

8. Bauersachs J, Jaisser F, Toto R. Mineralocorticoid receptor activation and mineralocorticoid receptor antagonist treatment in cardiac and renal diseases. Hypertension. 2015;65:257-63

9. Javaheri S. Heart failure. In: Reference Module in Neuroscience and Biobehavioral Psychology. Elsevier, 2017; p. 374-86.

10. Kurmani S, Squire I. Acute heart failure: definition, classification and epidemiology. Curr Heart Fail Rep. 2017;385-92.

11. Orso F, Fabbri G, Maggioni A Pietro. Epidemiology of heart failure. In: Bauersachs J, Butler J, Sandner P, editors. Handbook of Experimental Pharmacology (1st ed). Springer, 2017.

12. Ziaeian B, Fonarow GC. Epidemiology and aetiology of heart failure. Nature Reviews Cardiology. Nature Reviews Cardiology. 2016;13:368-78.

13. Neumann FJ, Sousa-Uva M, Ahlsson A, Alfonso F, Banning AP, Benedetto U, et al. 2018 ESC/EACTS Guidelines on myocardial revascularization. Eur $\mathbf{J}$ Cardio-thoracic Surg. 2019;40(2):87165.

14. Lainscak M, Spoletini I, Coats A. Definition and Classification of Heart Failure. Int Cardiovasc Forum J. 2017;10. DOI: 10.17987/icfj.v10i0.419.

15. Roger VL. Heart Failure. In: International Encyclopedia of Public Health, 2016; p. 520-6. Elsevier Inc.. https://doi.org/10. 1016/B978-0-12-803678-5.00199-5.

16. Redfield MM. Heart failure with preserved ejection fraction. New Eng $\mathrm{J}$ Med. 2016;375:1868-77.

17. Harper AR, Patel HC, Lyon AR. Heart failure with preserved ejection fraction. Clin Med J R Coll Physicians London. 2018; 18(2):24-9. 
18. Hsu JJ, Ziaeian B, Fonarow GC. Heart Failure with mid-range (borderline) ejection fraction. JACC Hear Fail. 2017;5(11): 763-71.

19. Bloom MW, Greenberg B, Jaarsma T, Januzzi JL, Lam CSP, Maggioni AP, et al. Heart failure with reduced ejection fraction. Nat Rev Dis Prim. 2017;3(1):17058.

20. Armstrong PW, Pieske B, Anstrom KJ, Ezekowitz J, Hernandez AF, Butler J, et al. Vericiguat in patients with heart failure and reduced ejection fraction. $\mathrm{N}$ Engl J Med. 2020;382(20):1883-93.

21. Shah KS, Xu H, Matsouaka RA, Bhatt DL, Heidenreich PA, Hernandez AF, et al. Heart failure with preserved, borderline, and reduced ejection fraction: 5-year outcomes. J Am Coll Cardiol. 2017; 70(20):2476-86

22. Kumar V, Abbas AK, Aster J. Robbins \& Cotrans Basic Pathology (9th ed). Elsevier Saunders, 2013.

23. Nappi JM, Sieg A. Aldosterone and aldosterone receptor antagonists in patients with chronic heart failure. Vasc Health Risk Manag. 2011; 2011(7):353-63.

24. McMurray JJV, Solomon SD, Inzucchi SE, Kober L, Kosiborod MN, Martinez FA, et al. Dapagliflozin in patients with heart failure and reduced ejection fraction. N Engl J Med. 2019;381(21):1995-2008.

25. Satizabal CL, Beiser AS, Chouraki V, Chêne G, Dufouil C, Seshadri S. Incidence of dementia over three decades in the Framingham heart study. N Engl J Med. 2016;374(6):523-32.

26. Inamdar A, Inamdar A. Heart failure: diagnosis, management and utilization. $\mathrm{J}$ Clin Med. 2016;5(7):62.

27. PERKI. Pedoman Tatalaksana Gagal Jantung (1st ed). Jakarta: PERKI; 2015.

28. Ellison DH, Felker GM. Diuretic treatment in heart failure. New Eng J Med. 2017; 377(20):1964-75.

29. Verma A, Kalman JM, Callans DJ. Treatment of patients with atrial fibrillation and heart failure with reduced ejection fraction. Circulation. 2017;135(16): 1547-63.

30. Lainscak M, Pelliccia F, Rosano G, Vitale C, Schiariti M, Greco C, et al. Safety profile of mineralocorticoid receptor antagonists: spironolactone and eplerenone. Int J Cardiol. 2015;200:25-9.

31. Berecek KH, King SJ, Wu JN. Angiotensin- converting enzyme and converting enzyme inhibitors. In: Raizada MK, Philips MI, Summers C, editors. Cellular and Molecular Biology of the Renin-Angiotensin System. CRC press, 2018.

32. Hubers SA, Brown NJ. Combined angiotensin receptor antagonism and neprilysin inhibition. Circulation. 2016; 133(11): 1115-24.

33. Arumugam S, Sreedhar R, Thandavarayan RA, Karuppagounder V, Krishnamurthy $\mathrm{P}$, Suzuki K, et al. Angiotensin receptor blockers: Focus on cardiac and renal injury. Trends Cardiovasc Med. 2016; 26(3):221-8.

34. Takeda A, Martin N, Taylor RS, Taylor SJC. Disease management interventions for heart failure. Cochrane Database Syst Rev. 2019;1(1):CD002752.

35. Lopes RD, Rordorf R, De Ferrari GM, Leonardi S, Thomas L, Wojdyla DM, et al. Digoxin and mortality in patients with atrial fibrillation. J Am Coll Cardiol. 2018;71(10):1063-74.

36. Garthwaite SM, McMahon EG. The evolution of aldosterone antagonists. Mol Cell Endocrinol. 2004;217(1-2):27-31.

37. Fagart J, Wurtz JM, Souque A, Hellal-Levy C, Moras D, Rafestin-Oblin ME. Antagonism in the human mineralocorticoid receptor. EMBO J. 1998; 17(12):331725.

38. Greenblatt DJ, Koch Weser J. Adverse Reactions to Spironolactone: A Report From the Boston Collaborative Drug Surveillance Program. JAMA J Am Med Assoc. 1973;225(1):40-3.

39. Funder JW, Feldman D, Highland E, Edelman IS. Molecular modifications of antialdosterone compounds: Effects on affinity of spirolactones for renal aldosterone receptors. Biochem Pharmacol. 1974;23(10):1493-501.

40. de Gasparo M, Joss U, Ramjoué HP, Whitebread SE, Haenni H, Schenkel L, et al. Three new epoxy-spirolactone derivatives: Characterization in vivo and in vitro. J Pharmacol Exp Ther. 1987; 240(2):650-56

41. Hu X, Li S, McMahon E, Lala D, Rudolph A. Molecular mechanisms of mineralocorticoid receptor antagonism by eplerenone. Mini-Reviews Med Chem. 2005;5(8):709-18. 
42. Kolkhof P, Borden SA. Molecular pharmacology of the mineralocorticoid receptor: Prospects for novel therapeutics. Mol Cell Endocrinol. 2012;350(2):310-7.

43. Cook CS, Berry LM, Bible RH, Hribar JD, Hajdu E, Liu NW. Pharmacokinetics and metabolism of [14C] eplerenone after oral administration to humans. Drug Metab Dispos. 2003;31(11): 1448-55.

44. Katzung BG, Masters SB, Trevor AJ, editors. Basic \& Clinical Pharmacology. New York: McGraw-Hill, 2012. Available from: https://pharmacomedicale.org/ images/cnpm/CNPM_2016/katzungpharmacology.pdf

45. Yancy CW, Jessup M, Bozkurt B, Butler J, Casey DE, Colvin MM, et al. 2017 ACC/AHA/HFSA focused update of the 2013 ACCF/AHA guideline for the management of heart failure: a report of the American College of Cardiology/ American Heart Association Task Force on Clinical Practice Guidelines and the Heart Failure Society of America. J Card Fail. 2017;23(8): 628-51.

46. Moore KP, Aithal GP. Guidelines on the management of ascites in cirrhosis. Gut. 2006;55(6):1-12.

47. Kapur G, Valentini RP, Imam AA, Mattoo TK. Treatment of severe edema in 20 children with nephrotic syndrome with diuretics alone - a prospective study. Clin J Am Soc Nephrol. 2009;4(5):907-13.

48. Layton AM, Eady EA, Whitehouse H, Del Rosso JQ, Fedorowicz Z, van Zuuren EJ. Oral spironolactone for acne vulgaris in adult females: a hybrid systematic review. Am J Clin Dermatol. 2017; 18(2):169-91.

49. Cumming DC. Use of spironolactone in treatment of hirsutism. Cleve Clin J Med. 1990;57(3):285-7.

50. Xu DL, Bai YJ. Interpretation of 2017 ACC/ AHA/HFSA focused update of the 2013 ACCF/AHA guideline for the management of heart failure. Chinese Gen Pract. 2017;20(29):3579-83.

51. Patibandla S, Heaton J, Kyaw H. Spironolactone. StatPearls Publi-shing; 2020; Available from: https://www.ncbi.nlm. nih.gov/books/NBK554421/

52. Vecchiola A, Lagos CF, Carvajal CA, Baudrand R, Fardella CE. Aldosterone production and signaling dysregulation in obesity. Current Hypertension Reports. 2016;18(3):1-9.

53. Craigie E, Evans LC, Mullins JJ, Bailey MA. Failure to downregulate the epithelial sodium channel causes salt sensitivity in hsd11b2 heterozygote mice. Hypertension. 2012;60(3):684-90.

54. Hirata A, Maeda N, Nakatsuji H, HiugeShimizu A, Okada T, Funahashi T, et al. Contribution of glucocorticoid-mineralocorticoid receptor pathway on the obesity-related adipocyte dysfunction. Biochem Biophys Res Commun. 2012; 419(2):182-7.

55. De Marco VG, Habibi J, Jia G, Aroor AR, Ramirez-Perez FI, Martinez-Lemus LA, et al. Low-dose mineralocorticoid receptor blockade prevents western dietinduced arterial stiffening in female mice. Hypertension. 2015;66(1):99-107.

56. Sakamoto T, Fujii A, Saito N, Kondo H, Ohuchi A. Alteration of amiloridesensitive salt taste nerve responses in aldosterone/ $\mathrm{NaCl}$-induced hypertensive rats. Neurosci Res. 2016;108:60-6.

57. Ferreira JP, Rossignol P, Machu J-L, Sharma A, Girerd N, Anker SD, et al. Mineralocorticoid receptor antagonist pattern of use in heart failure with reduced ejection fraction: findings from BIOSTAT-CHF. Eur J Heart Fail. 2017; 19(10):1284-93.

58. Durstenfeld MS, Katz SD, Park H, Blecker S. Mineralocorticoid receptor antagonist use after hospitalization of patients with heart failure and post-discharge outcomes: A single-center retrospective cohort study. BMC Cardiovasc Disord. 2019;19(1):1-9.

59. Bruno N, Sinagra G, Paolillo S, Bonomi A, Corrà U, Piepoli $M$, et al. Mineralocorticoid receptor antagonists for heart failure: a real-life observational study. ESC Hear Fail. 2018;5(3):267-74.

60. Serenelli M, Jackson A, Dewan P, Jhund PS, Petrie MC, Rossignol P, et al. Mineralocorticoid receptor antagonists, blood pressure, and outcomes in heart failure with reduced ejection fraction. JACC Hear Fail. 2020;8(3):188-98.

61. Papademetriou V, Toumpourleka M, Imprialos KP, Alataki S, Manafis A, Stavropoulos K. The role of mineralocorticoid receptor antagonists in heart failure with reduced ejection fraction. Curr Pharm 
Des. 2019;24(46):5517-24.

62. Desai AS, Vardeny O, Claggett B, McMurray JJV, Packer M, Swedberg K, et al. Reduced risk of hyperkalemia during treatment of heart failure with mineralocorticoid receptor antagonists by use of sacubitril/valsartan compared with enalapril: A secondary analysis of the PARADIGM-HF trial. JAMA Cardiol. 2017;2(1):79-85.

63. Saleh MAM, Mohammed GR, Ibrahim AMA, Solhy MM. A Comparison between both mineralocorticoid receptor antagonist agents (eplerenone and spironolactone) in prognosis of heart failure with reduced ejection fraction (HFrEF). Egypt J Hosp Med. 2019;76(2):3516-22.

64. Alsoud LO, Atallah B, Sadik ZG, Ghalib H, AlSindi F, Bader F. Utilization of mineralocorticoid receptor antagonists in an advanced heart failure and transplant program in the Middle East. J Card Fail. 2020;26(10):S25.

65. Berbenetz NM, Mrkobrada M. Mineralocorticoid receptor antagonists for heart failure: Systematic review and metaanalysis. BMC Cardiovasc Disord. 2016;16(1):246. 